\title{
Observing Current National Education System
}

\author{
Ahmad \\ Universitas Muhammadiyah Purwokerto \\ ahmadump@yahoo.co.id
}

\begin{abstract}
Considering an important role of education for people's life, it is currently required a development of national education system which is in accordance with demands of globalization era. It can help Indonesian government implementing its hard effort to set the education system rises and grows rapidly, so it can be a front guard of the national development. The effort of developing national education system is specifically reflected in the government's policies such as providing means of legislation, increasing education budget, and also completing various regulation issued to improve national education.
\end{abstract}

Keywords: observing, development, system, national education.

\section{INTRODUCTION}

Currently, both national and regional governments completely focus on implementation of education development and its progress in order to improve quality of human resources believed as supporting factors of regional progress accelerator. The development of education in each region is based on the three pillars of the Strategic Policy of Indonesian Ministry of National Education, namely: 1) Expanding and equitable access to education, 2) Improving quality, relevance, and competitiveness, and 3) Governance, accountability and public imaging [6] 5). Currently, these three pillars are the basis for the development of the entire education sector in Indonesia.

With the issuance of regional autonomy officially implemented since January 1, 2001, the development of education based on the three pillars is also the responsibility of local governments respectively. This is in line with the demands of the national reformation which gradually lead to the implementation of wider regional autonomy. In the field of education, demands of the reformation are more directed to the decentralization process of education management [2].

To be able to achieve itself as a winner, then mastery of science and technology becomes something very important as a precondition to anticipate changes to a nation not to be left behind. It should also be stated that the existence of a nation in the era of globalization is greatly colored by the race to reach the peak of science. Related to the fact, Hatten \& Resenthal [8] stated that mastery of science and technology in an adequate level is needed, so that people can improve their ability of creativity, development, and application of science and technology as an absolute demand in global life.

\section{IMPACT OF GLOBALIZATION TOWARD EDUCATION}

As a consequence of these developments, the government is required to innovate the higher education system in accordance with the demands of change in a pattern of coaching, which places higher education as: 1) an integral part of national and regional development, 2) a connector between the world of science and technology and the needs of society, 3) an effort to develop analytical patterns oriented to problem solving with future views, 4) a form of participation in improvement and development of life and culture quality, science and its application, understanding and international cooperation in an effort to achieve world peace and welfare of mankind, and 5) an effort to enable the development of all human capabilities and personality, mobility in gaining educational experience, diversification, democratization in education, learning process, mobilization of community resources for education and growth of excitement of research activities.

Basically, fast-growing globalization is driven by three important factors often called three engines of globalization namely technology, capital, and management. All these three are devices interconnected with each other. The development of new technology has been able to facilitate movement and expansion of capital from one place to another. Meanwhile, modern management of economists has been able to prepare the company and set the strategy in order to work together or to win the competition supported by capital and technology. Sophisticated modern management can certainly encourage managers to manage the company well.

In a world that is constantly changing and colored by social and economic innovation, education appears to be one of the driving forces to improve the quality of imagination and creativity as an expression of human freedom and the standardization of individual behavior. Opportunities need to be given to the youths to try doing their best and to discover something new [10].

Thus the process of education is not solely to deepen knowledge, but also emphasized to enhance the critical attitude and creative power of learners. This is very necessary considering the diversity of challenges in the future is very demanding of such abilities. Today, we are often required to be able to answer in a short response times and often a challenge requires multiple responses at once. 


\section{DECENTRALIZATION OF EDUCATION IN INDONESIA}

In general, the main objectives of decentralization of education in Indonesia are as follow: 1) Reducing the burden on the central government and intervening on small issues at the local level. 2) Improving people's understanding and their support in socio-economic development. 3) Establishing a realistic program of socio-economic improvement at the local level. 4) Training the people to manage their own business. 5) Fostering national unity. The central government (Department of of National Education) delegates some of its affairs to vertical agencies at its lower levels carefully through the trial process. Basically, the implementation spirit of decentralization of education cannot be separated from the expansion of access to primary education (Public and Islamic primary schools) in the regions through the 9-year compulsory education program.

In line with the continuous improvements towards decentralization of education, all societies in this country have great hopes for improving education through government policies. The polecies are Law Number 20 of 2003 on the National Education System, Law Number 14 of 2005 on Teachers and Lecturers, as well as improvements at the level of curriculum at every level of education are conducted in order to meet the needs of society and global challenges. In current global era, education is very important as a pre-requisite of mastery of science and technology, so that a nation can anticipate changes that are massive and complex. Thus, the dynamics of a nation in the global era is greatly colored by the competition to reach the peak of science. For a nation to exist in this globalization era, the mastery of science and technology in an adequate level including the ability to creativity, develop and apply it is an absolute demand [8].

High quality education is needed in order to create a society that is intelligent, peaceful, open, democratic, and competitive. This in turn will improve the welfare of society as a whole. The curriculum improvements are carried out responsively to the application of human rights, democratic life, globalization, and regional autonomy [5].

\section{QUALIFICATION STANDARD OF EDUCATION}

Variable of graduates to measure quality of education is not enough if measured by local or national standards only. This is because the global era has opened local and national barriers as a quality standard in any field. Thus, a successful nation is a highly educated nation with high quality in accordance with global standards. The government through the Law on National Education System and the Law on Teachers and Lecturers has set what will be developed through the model that should be used. This is inseparable from the curriculum orientation as an effort to develop the learners themselves, the development of disciplines. In other words, the curriculum is developed in various fields of science that aims to prepare learners on a certain competitive ability [7].

Academic competence is the scientific foundation of the provision of teacher services including: a) ability to know the students in depth, b) ability to master the field of study, c) ability to provide educational learning, and d) ability to develop the profession in a sustainable manner. Then, professional competence can be established through the application of academic competence in schools. Therefore, in reality academic competence and professional competence is an integrated ability and cannot be separated [3].

\section{POLICY ON DEVELOPMENT OF TEACHER EDUCATION SYSTEM}

The future of the education system in Indonesia is not solely about efforts to improve the quality and efficiency of education internally, but it is also required to improve the conformity of education with the more complex sectors of life (Danin, 2002: 17, Ibrahim, 1998: 2).

The education is required to produce human resources who are in accordance with the advancement of technology and culture that developed in society. It because education is an effort to realize the goals of national development. Specifically the objectives of national development in education are stated in Law No. 20 of 2003 on National Education System. It states that:

National Education is functioned to develop the ability and to build the character and civilization of a dignified nation, in order to educate the nation's life. It aims to develop potential of learners to be human who believes and cautious to God Almighty, noble, healthy, knowledgeable, capable, creative, independent, and become a democratic and responsible citizen (Article 3 of Law of RI No. 20 of 2003)

In order to implement four pillars of education (initiated by UNESCO), Indonesia improves itself through a series of educational policies. One of the policies can be observed in Law Number 14 of 2005 on Teachers and Lecturers that lead to increase teacher resources. The teacher's position is expressly stated in Law Number 14 of 2005 on Teachers and Lecturers Chapter II Article 2 affirmed: teachers have positions as professionals at elementary, secondary, and early childhood education levels in the formal education channels that are appointed in accordance with the laws and regulations. Furthermore, in Article 4 stated that the position of teachers as professionals serves to improve the dignity and role of teachers as learning agents serves to improve the quality of national education.

\section{DEMANDS OF TEACHER PROFESSION IN INDONESIA}

Considering the fact of teacher as a professional profession, it is required for them to have a number of professional competencies. Regarding the functional 
position of the teacher refers to the position that indicates duty, responsibility, authority, and right of a teacher performing tasks based on mastery or certain skill and is independent. Based on the above explanation it can be stated, that the whole figure of professional competence of teachers is a set of skills that should be owned by teachers in line with the educational needs required by the curriculum and schools, as well as the demands of society and the development of science and technology. In general, a teacher's achievement is marked by the achievement of professional competence.

Competencies in question include the competence of process skills and knowledge mastery, which can be explained as follows:

\section{Competence of Learning Process.}

It is a mastery of skills related to the learning process including planning capabilities, implementation, and evaluation of learning, as well as the ability to analyze and to arrange improvement and enrichment programs, and to develop special guidance and counseling programs for primary school teachers.

\section{Competence of Knowledge Mastery}

It is a mastery of competencies related to breadth and depth of knowledge. These competencies include understanding of educational insights, self-development and professions, potential development of learners, and academic mastery.

Thus, education has the function and potential to make preparations for change in society which is in accordance with the demands of globalization. In this case the school as an educational institution is not only required to teach science, but must be able to produce learners who become independent change actors. Therefore, the school is challenged to be more reliable in giving its role as an effort to prepare students to anticipate global demands [11]. Regarding the values that become the reference are:

1. Input values, in order to achieve Trustworthiness, Professional and Confident, Enthusiastic and Highly Motivated, Responsible, Creative, Discipline and Caring.

2. Process values, in order to achieve and maintain the desired conditions, namely visionary and insightful, being example, motivating, inspiring, empowering, culturing-forming principles, co-ordinate and synergize in team framework, and accountable.

3. Output values; the values that are noticed by the stakeholders including productive, gandrung, high quality/excellent service, trustworthy (reliable), responsive andaspirational, anticipatory and innovative, democratic, fair, exclusive, and long life learning.

In that context, every educational institution at every level is highly skilled that has sufficient ability to be able to achieve the targets outlined.

\section{CONCLUSION}

The era of globalization that is marked by rapid changes, can be an obstacle, challenge, as well as many opportunities. To be able to place globalization as an opportunity, then the conditions that must be met is the mastery of science and technology, capital, and management capabilities (three globalization engines). This strategy can only be achieved by providing an adequate education system for the young generation in accordance with the demands of the global era

Certainly the demands on the implementation of the education system in the global era are closely related to the improvement of academic and professional competence of teachers and other education personnel. It is feasible as a material consideration of teachers and education personnel as the main role in the implementation of education and learning in school. Considering the importance of teachers and educational personnel to take part in preparing students who have competitiveness in the future, the educational system developed should be able to improve their competence, both related to academic competence and professional competence. Thus, high performance can be achieved and the achievement of learning targets generated as expected.

\section{REFERENCES}

[1] Danin, S., Inovasi Pendidikan, Bandung, Pustaka Setia, 2002.

[2] Supriadi, D., Reformasi Pendidikan Dalam Konteks Otonomi Daerah, Yogyakarta, Adicita. 2000.

[3] Depdiknas, Pola Pembinaan Sistem Pendidikan Tenaga Kependidikan PGSD, Jakarta, Depdiknas. 2004.

[4] Depdiknas, Undang-Undang RI Nomor 14 Tentang Guru Dan Dosen, Jakarta, Depdiknas. 2005.

[5] Depdiknas, Standar Kompetensi Guru Kelas SD/MI Lulusan S 1 PGSD, Jakarta, Depdiknas. 2006.

[6] Depdiknas, Standar Pembangunan Pendidkan Nasional, Jakarta, Depdiknas. 2008.

[7] Hasan, S.H., Kurikulum dan Tujuan Pendidikan, Bandung, Pasca Sarjana UPI. 2004.

[8] Hatten, K.J, \& Rosenthal, S.R., Reaching for the Knowledge Edge, New York, American Management Association. 2001.

[9] Ibrahim, Inovasi Pendidikan, Jakarta, Ditjen Dikti Depdikbud, Jakarta. 1998.

[10] UNESCO, Learning: Treasure Within, New York, UNESCO Publishing. 1996.

[11] Widayati,S, Reformasi Pendidikan Dasar, Jakarta, Grasindo. 2002. 